УДК: 355.23(477):378.5

Дмитро Анатолійович Чопа (кандидат технічних наук, с.н.с.) ${ }^{1}$

Анатолій Йосипович Дерев'янчук (кандидат технічних наук, професор) ${ }^{2}$

Наталія Миколаӥвна Козир

${ }^{1}$ Національний університет оборони Украйни імені Івана Черняховського, Київ, Украӥна

${ }^{2}$ Сумський держсавний університет, Суми, Украӥна

${ }^{3}$ Науково-дослідний центр Ракетних військ і артилеріӥ, Суми, Украӥна

\title{
ОСНОВНІ ІННОВАЦІЙНІ НАПРЯМИ ЗАСТОСУВАННЯ СУЧАСНИХ ІНФОРМАЦІЙНИХ ТЕХНОЛОГІЙ У ПІДГОТОВЦІ ВІЙСьКОВИХ ФАХІВЦІВ
}

\begin{abstract}
Застосування Збройних Сил Украӥни в сучасних умовах обумовлює нові вимоги до організаціі навчання та підготовки військових фахівців. Існує нагальна потреба в розробленні нових технологій навчання, підвищенні рівня засвоювання навчального матеріалу та удосконаленні способів контролю його засвоєння. Тому в статті на основі досвіду кафедри військової підготовки Сумського державного університету наводяться основні інноваційні напрями застосування інформаційних технологій у підготовиі військових фахівців (на прикладі фахівців РВ і А). А саме, ия стаття присвячена створенню мультимедійних віртуальних тренажерів (симуляторів), моделюванню навчальних ігор, розробленню системи автоматизованої оцінки знань та розробленню інформаційно-дистанційно-тренажерноі системи навчання. Автори статті продовжують ділитися власним досвідом щзодо концепції застосування сучасних методів викладання військово-технічних дисциплін з метою подальшого їх обговорення, розвитку та впровадження в освітній процес ВВНЗ.

Ключові слова: інформаційні технології, мультимедійні віртуальні тренажери (симулятори), навчальні ігри, система автоматизованої оцінки знань, інформачійно-дистанційно-тренажерна
\end{abstract} система навчання.

\section{Вступ}

Дану статтю слід розглядати як подальший аналіз технічних основ розвитку сучасних методів викладання військово-технічних дисциплін (ВТД), які були сформульовані та висвітлені у роботах [1-2].

Постановка проблеми. Традиційні методи підготовки фахівців РВ і А вже не можуть певною мірою забезпечувати виконання ними бойових завдань, використання озброєння та військової техніки (ОВТ) за призначенням. Це змушує безперервно вести пошук нових технологій у вивченні ВТД на фоні зростаючого постачання нових зразків ОВТ у війська.

Як свідчить досвід локальних війн і збройних конфліктів минулого, проведення ООС (АТО) на сході України, підготовлені на високому технічному рівні підрозділи вели бойові дії 3 малими втратами особового складу і ОВТ.

Iз наведеного вище випливає пріоритетне завдання, на основі визначених інноваційних напрямів застосування сучасних інформаційних технологій створити новітню систему вивчення ВТД, яка б забезпечувала комплексну підготовку фахівців 3 теоретичних знань i практичних навиків.

Мета i актуальність статті полягає у подальшому розвитку інноваційних напрямів застосування інформаційних технологій, що у підсумку створить комплексну систему якісної підготовки військових фахівців.

\section{Виклад основного матеріалу} дослідження

У роботі [1] розглянуто перші три інноваційні напрями застосування сучасних інформаційних технологій у викладанні ВТД.

Пропонуються до розгляду i осмислення наступні чотири інноваційні напрями, саме: розроблення мультимедійних віртуальних тренажерів (симуляторів); моделювання навчальних ігор; розроблення системи автоматизованої оцінки знань; розроблення інформаційної-дистанційно-тренажерної системи навчання.

\section{Інноваційний напрям 4. Розроблення} мультимедійних віртуальних тренажерів (симуляторів).

Загальновідомо, що в особливий період в країні, коли йдуть бойові дії на сході, різко збільшилося ОВТ, яке потребує ремонту, відновлення. Відомо також, що військові фахівці і персонал ремонтних органів ще не мають потрібної кваліфікації для поводження з ОВТ та його ремонту і відновлення, що в свою чергу, висуває завдання розроблення та впровадження спеціалізованих комп'ютерних (віртуальних) тренажерів, застосування яких підвищить кваліфікацію як фахівців, так і персоналу, що обслуговує ОВТ, зменшить витрати на закупівлю дорогої техніки та ЗІП до неї, а обслуговуючий 
персонал зможе отримувати навики поводження у нештатних ситуаціях тощо. Практичні заняття допомагають відпрацьовувати отримані навики у безпечному віртуальному середовищі. Віртуальні тренажери надають можливість обрати не тільки індивідуальний підхід до навчання, але й зручний $\mathrm{i}$ гнучкий режим заняття. При розробці віртуальних тренажерів необхідно враховувати наступне [2]: інтерфейс повинен бути максимально наближений до реальних зразків озброєння (пульти, щитки управління, ключі, ЗІП, механізми тощо); динамічна модель (3D модель) повинна враховувати основні реальні процеси взаємодії вузлів і механізмів ОВТ; всі додатки повинні бути прості і гнучкі; інструктору (керівнику заняття) надана можливість змінювати сценарій шляхом введення нештатних ситуацій; тренажер повинен робити аналіз і оцінку дій фахівця.

Так, розроблений нами тренажер, може використовуватися у наступних режимах: читання i огляд матеріалу; пошук потрібних матеріалів; друкування матеріалів (за бажанням замовника); перевірка знань; перегляд довідникового матеріалу.

У режимі читання користувач переглядає текстову частину обраного питання. Доступ до матеріалів стосовно іншого питання реалізується у вигляді гіперпосилання на графічні елементи або інші текстові розділи. Натиснувши на гіперпосилання, в окремому вікні відкривається відповідний текст, графічний або відео матеріал.

Процес навчання із використанням віртуального тренажера показано на схемі (рис. 1). Такий комп'ютерний тренажер містить в собі сукупність програмних і апаратних засобів, що дозволяє здійснювати процес навчання без безпосередньої взаємодії фахівця i реального зразка озброєння. Апаратні можливості тренажера - це сучасний персональний комп'ютер, оснащений якісними пристроями вводу (виводу) інформації.

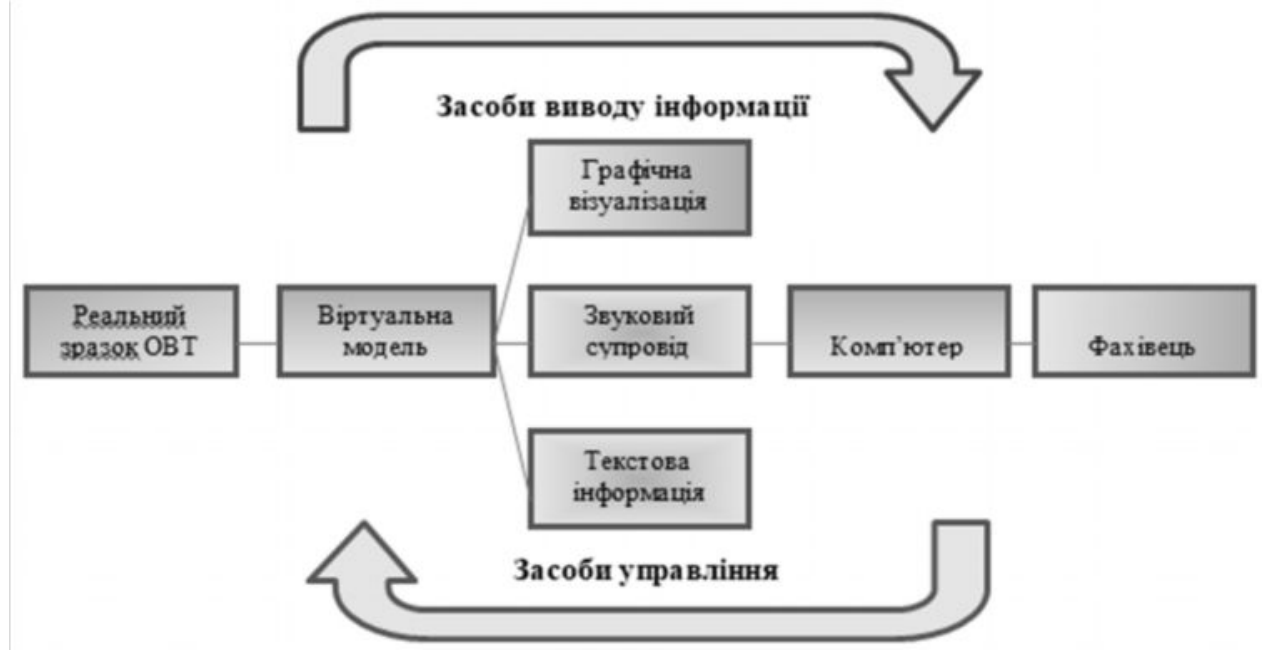

Рис. 1. Спрощена схема принципу роботи віртуального тренажера

Програмний засіб - це математично обгрунтована віртуальна модель, що містить в собі систему графічної візуалізації, звуковий супровід і текстову інформацію.

Ми пропонуємо декілька різновидів тренажерів різних за своєю сутністю та складністю. На рис. 2,3 надані зразки віртуальних тренажерів (зі складання бойових зарядів та затвору 122-мм гаубиці Д-30 відповідно).

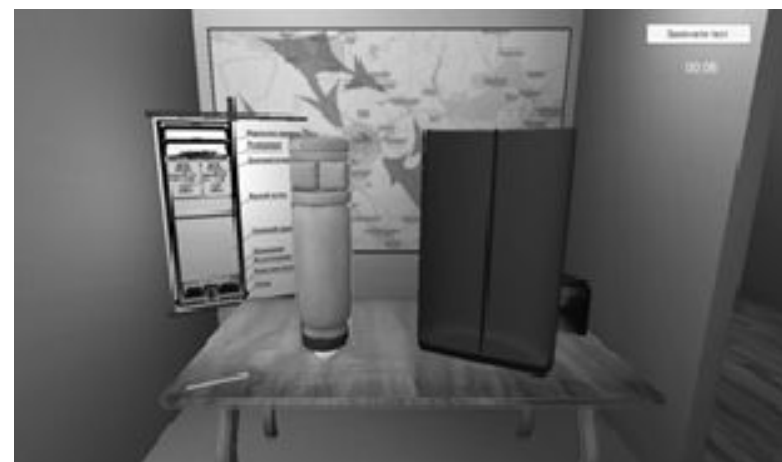

Рис. 2. Тренажер зі складання бойового заряду у робочому стані

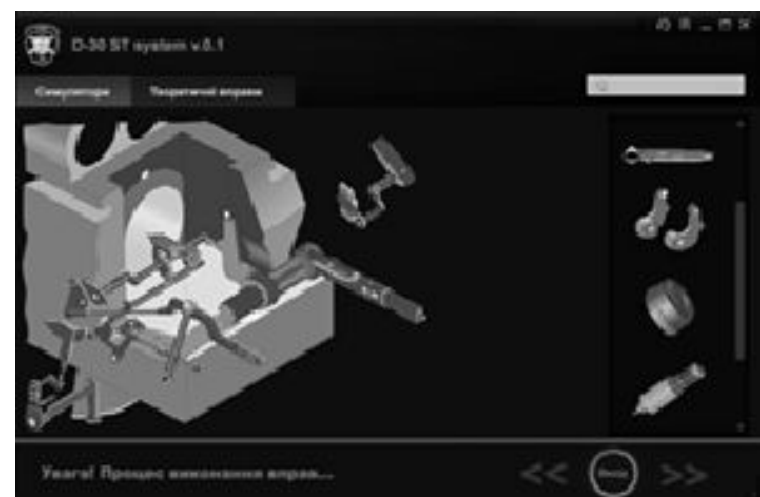

Рис. 3. Приклад практичного модуля (затвор) 122- мм гаубиці Д-30

Зазначені віртуальні тренажери працюють за єдиним алгоритмом, що представлений на рис.4.

Інновачійний напрям 5. Моделювання навчальних ігор.

Навчальна гра - це гра, що призначена навчити студентів щодо певного предмету та набути ними майстерності, а також це інтерактивна гра, яка навчає їх цілям, правилам, адаптації, вирішенню проблем, взаємодії. 


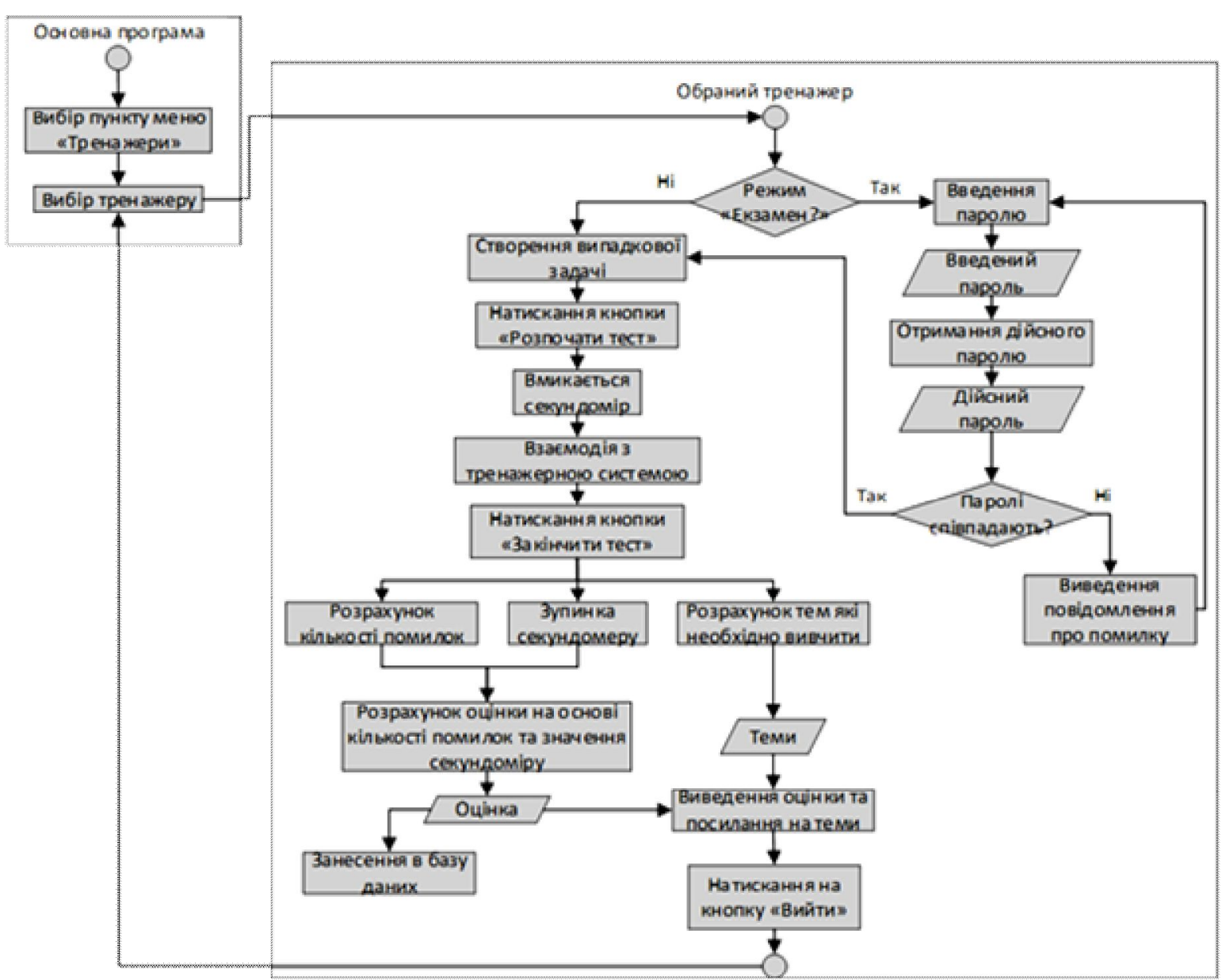

Рис. 4. Блок-схема алгоритму роботи віртуального тренажера

Такі ігри задовольняють основну потребу в навчанні, забезпечуючи зацікавленість, пристрасну участь, мотивацію, соціальну взаємодію та емоції в ході гри та, в той же час, навчання продовжується.

Військові завжди були користувачами або розробниками інноваційних технологій моделювання. Характер військових місій вимагає, щоб вони репетирували їх дуже часто для того, щоб краще зрозуміти їх складні взаємодії та оцінити результати. Ця потреба призвела до застосування моделювання низки різних заходів, використання комп'ютерних технологій в сфері навчання та використання навчальних ігор.

Прикладом використання навчальних ігор $\epsilon$ програма, що поєднує у собі інтелектуальну гру “філворд” 3 3D моделюванням (використанням реалістичних 3D моделей OBT).

Завданням користувача програми є збирання на ігровому полі слова за правилами гри “філворд”. Наступним кроком користувачу поруч 3 полем буде показана 3D модель слова, що було тільки-но зібране. Така послідовність дій пов'язує вербальну пам'ять із зоровою, що, в свою чергу, дозволяє покращити якість та швидкість навчання, запам'ятовування назв окремих деталей.

Дана комп'ютерна програма дозволяе непомітно для користувача продовжити навчання навіть під час відпочинку, зменшити час для отримання інформації, сформувати термінологічну грамотність студентів, підвищити зацікавленість у навчальному матеріалі, може візуалізувати об'єкт вивчення (за його фізичної відсутності).

В їі основу покладено алгоритм, зображений на рис. 5.

Об'єднавши методику навчальних ігор 3 комп'ютерними технологіями, а саме, електронним додатком, отримуємо потужний механізм навчання з такими вагомими перевагами: уникнення шаблонності побудови “філворду”; швидкість навчання (зібравши слово користувач побачить реалістичну 3D модель), тим самим використовується як зорова, так i вербальна пам'ять; кросплатформеність - програма однаково добре працює як на ПЕОМ, так і на смартфоні.

В програмі наданий рівень-словник, тобто якщо користувач лише хоче згадати як виглядає або називається той чи інший об'єкт, дізнатися точну будову деталі (особливо за іiі відсутності або недоступності) йому не доведеться грати знову і знову для отримання потрібного слова. Достатньо лише знайти у “Бібліотеці” потрібний об'єкт (слово).

Результатом впровадження ігрових методів навчання $€$ підвищення мотивації до вивчення дисципліни; підвищення якості запам'ятовування та утримання інформації.

Приклад ігрового поля зображено на рис. 6.

Авторська методика спирається на поєднанні зорової та вербальної пам'яті користувача. Ігрове поле має формальний поділ на 2 зони. Перша 3 яких присвячена “філворду”, а друга є полем для 
3D моделей. Спеціально створений алгоритм, що в основу своєї логіки дій бере випадкову генерацію чисел, будує поле “філворда" повністю унеможливлюючи повторення положення слів відносно генерованих ігрових полів попередньої сесії. Користувач повинен зібрати, за правилами

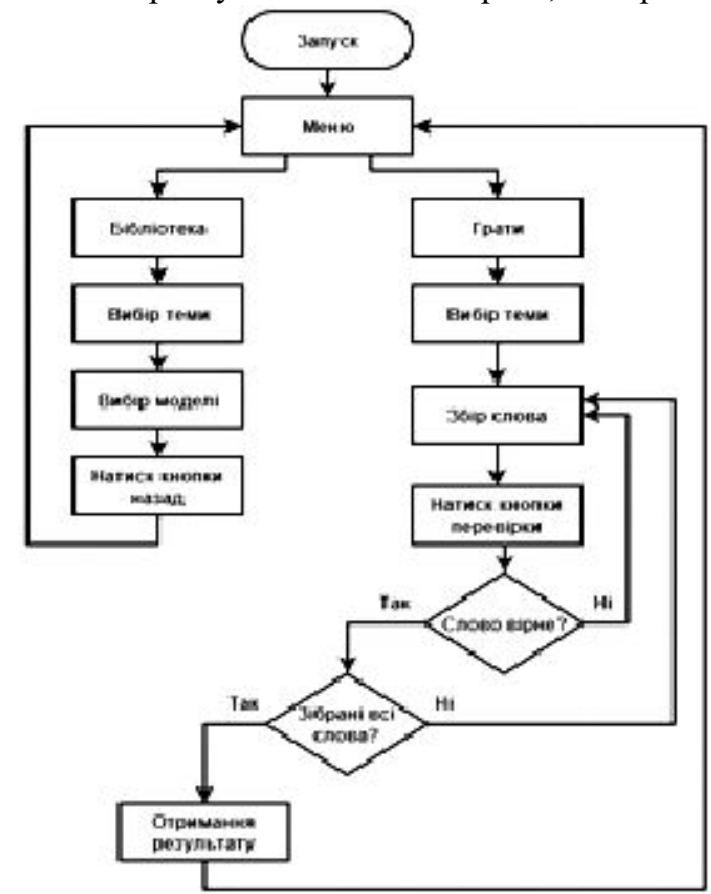

Рис. 5 Алгоритм програми

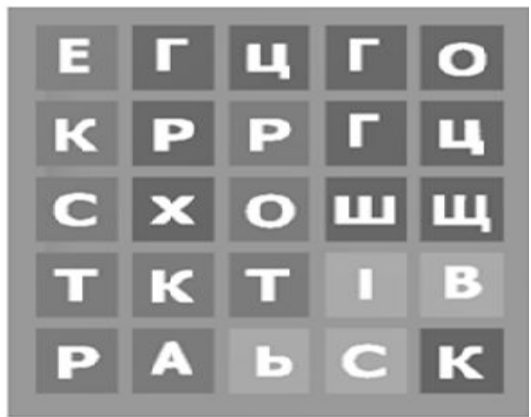

Рис. 6. Варіанти матриці ігрового поля: (обране слово-екстрактор)

Саме цей момент зв'язує в пам'яті студента слово $з$ його предметом.

Інновачійний напрям 6. Розроблення системи автоматизованої оцінки знань.

Наступним кроком до подальшого вдосконалення програмних продуктів стало дослідження засвоєння рівня навчального матеріалу студентами, де використовувались власні розроблені мультимедійні засоби навчання (МЗН). Була розроблена система автоматизованої оцінки якості знань (далі - система оцінки). Створена система оцінки містить в собі увесь навчальний матеріал, який використовується у МЗН, таким чином, що робота з системою оцінки якості знань збільшує ще на певний відсоток кількість інформації, що запам'ятовується, через використання принципу "повторюваності". Відповідаючи на запитання в системі оцінки, слухач візуально на екрані бачить той самий матеріал, що і у МЗН, відповідно до обраної теми. “філворду”, слово та підтвердити свій вибір. Якщо слово, що повинно бути назвою предмета, деталі, котру потрібно запам'ятати, справді існує то поруч 3 ігровим полем “філворду” з'явиться реалістична 3D модель цього предмета (рис.7).

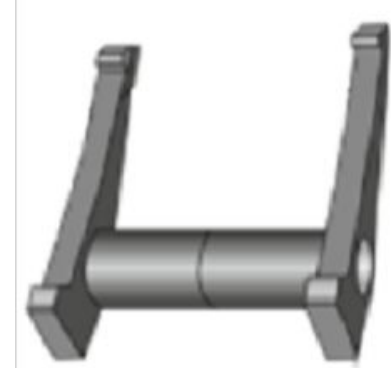

Рис. 7. Загальний вигляд 3D моделі екстрактора

Аналіз результатів дослідження показав не тільки підвищення рівня засвоєння навчального матеріалу, але й посилення мотивації студентів.

Саме це сприяло створенню системи оцінки, де поєднувалися програмні продукти навчальнометодичних матеріалів, а саме: комп'ютерні презентації ілюстративного характеру і електронні посібники, словники - довідники, і електронні тренажери, тестові системи, самовчителі, а користування ними викликало інтерес у студентів.

Загальна схема системи оцінки і взаємодії між його складовими подана на рис. 8.

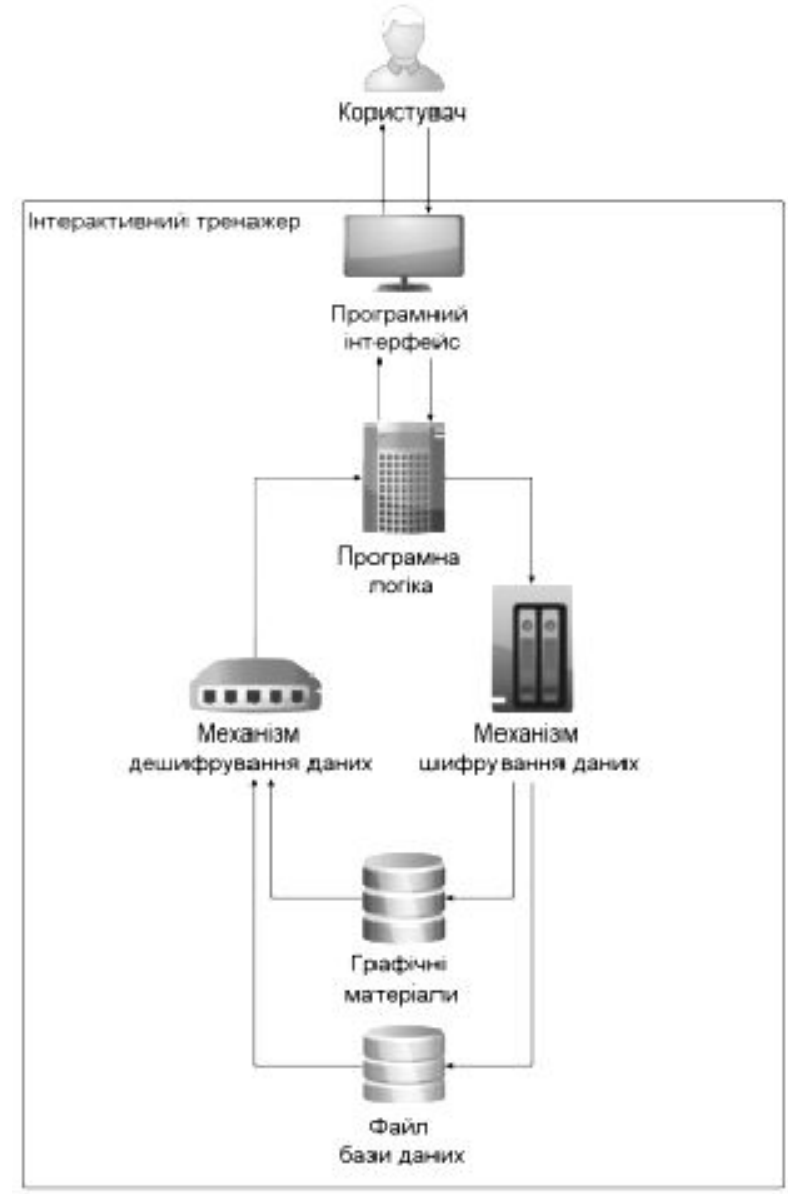

Рис. 8. Структура системи автоматизованої оцінки якості знань 
На рисунку зображено процес проведення оцінювання з використанням системи оцінки. Це студенти, які отримають певні знання та готуються до їх перевірки, комп'ютер із встановленою програмою, за допомогою якої система оцінки та слухачі обмінюються інформацією у діалоговому режимі, та, власне, сама система оцінки якості знань. За допомогою стрілок вказані напрями обміну інформацією між цими складовими. Розроблена система автоматизованої оцінки знань поєднує у собі можливості мультимедійного посібника та тренувального додатка. Ïї̈ застосування дозволяє суттєво підвищити рівень засвоюваності матеріалу слухачами та перевірити ïx знання за пройденими розділами. Простота користування та функціональність роблять систему оцінки однією 3 найкращих на ринку подібних програмних засобів, а якісні ілюстрації та відеоролики до матеріалу забезпечують високий конкурентоздатний рівень. Серед основних можливостей відзначимо наступні: легкий i зрозумілий інтерфейс; наявність “живих” ілюстрацій, анімацій та відеороликів до поставлених питань; влаштована система оцінювання знань; захищений файл-сховище даних, які використовує програма; наявність вбудованого редактора контрольних питань, що надає можливість додавати та змінювати існуючі питання; прозора система оцінювання знань студентів; наявність вбудованих підказок та посилань на навчальні матеріали курсу дисциплін; збереження детальної інформації про результати проходження тесту студентами; вбудована система аналізу помилок; для встановлення та роботи програми не потрібні жодні сторонні додатки; система оцінки поєднує в собі ретельно підібрані запитання, якісні і яскраві ілюстрації, відеоролики та сучасні технології роблять їі справжньою знахідкою для будь-якого військового навчального закладу.

Блок-схема алгоритму роботи програми зображена на рис. 9.

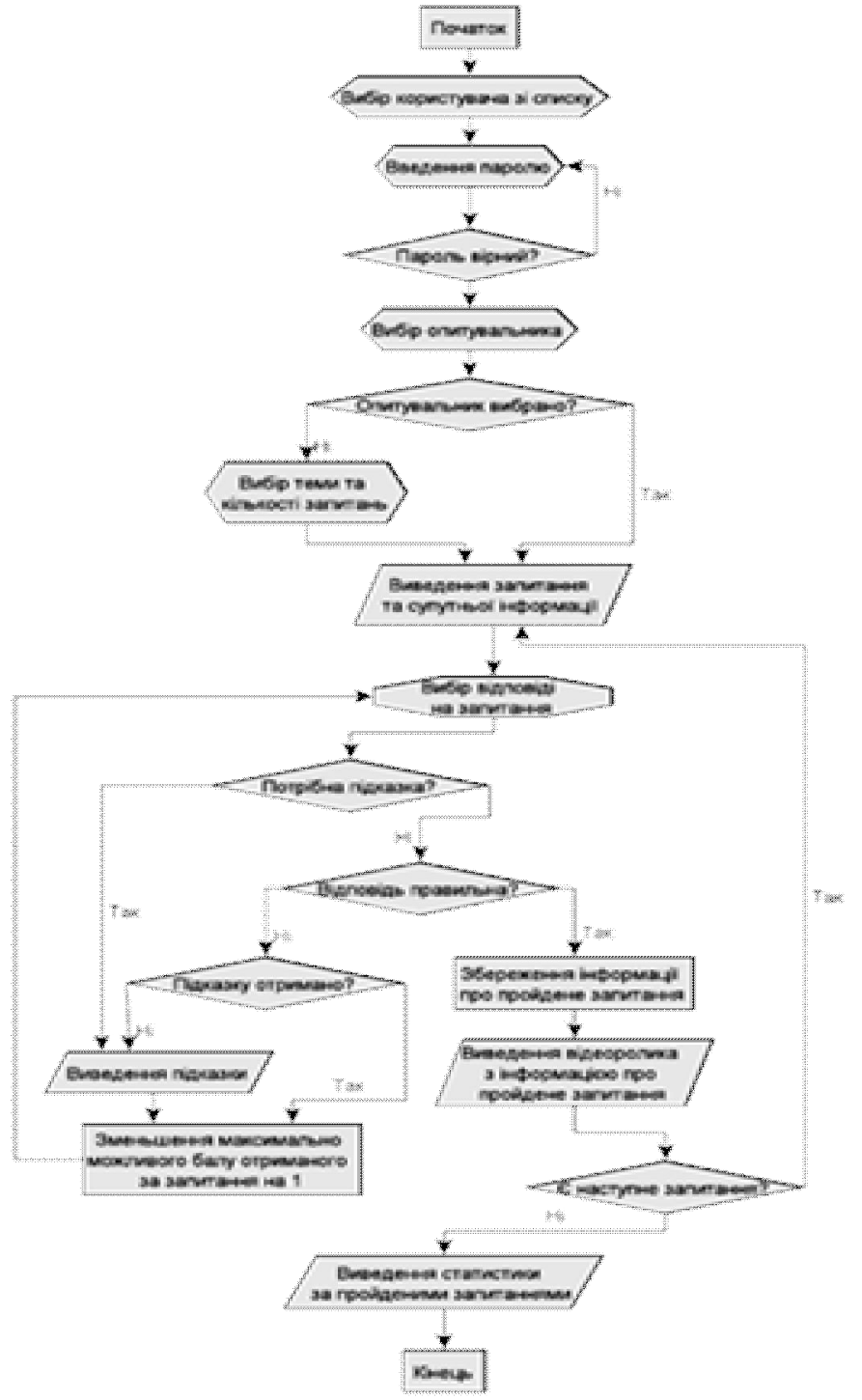

Рис. 9. Блок-схема алгоритму роботи системи оцінки знань

Аналіз успішності слухачів з різною загальноінженерною підготовкою наведені на рис. 10, 3 якого можна зробити висновок щодо доцільності використання розробленої автоматизованої оцінки якості знань.
При чому, аналіз проводить система оцінки, відповідно до співвідношення правильних відповідей на запитання наданих слухачам, та в автоматичному режимі будує діаграму успішності. 


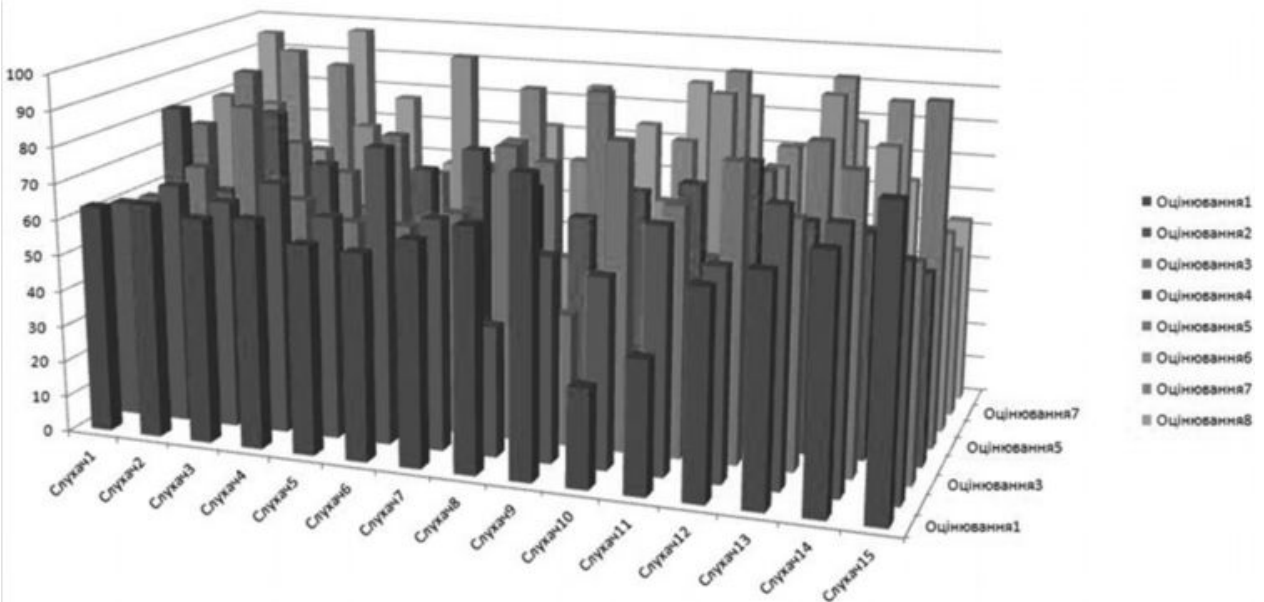

Рис. 10. Діаграма успішності рівня засвоєння теоретичних знань і практичних навиків

Таким чином, виходячи із викладеного i результатів дослідження, можна стверджувати, що впровадження системи оцінки у навчальний процес в системі підготовки військових фахівців має високу ефективність, а зменшення навантаження на викладача та можливість забезпечувати діалоговий режим у процесі вирішення конкретних питань роблять їх дуже корисними не тільки для ВВНЗ, а й для навчальних центрів, командирів військових частин і підрозділів.

Інновачійний напрям 7. Розроблення інформаційної-дистанційно-тренажерної системи навчання.

Немає сумніву в тому, що впровадження технологій дистанційного навчання у ВBН3 на теперішній час займає пріоритетний напрямок. Ця теза підтверджується тим, що у листопаді 2018 року у Києві відбулася перша міжнародна науково-практична конференція, присвячена проблемам впровадження дистанційного навчання під егідою Інституту Джефферсона (США) [3]. Це стосується також військових кафедр і факультетів, що готують офіцерів запасу. Таке пояснюється тим, що матеріально-фінансові можливості студентів, що мешкають за межами навчальних закладів, обмежені як за часом, так і відсутністю навчальних зразків ОВТ. Основною проблемою у підготовці фахівців є неможливість відпрацювання практичних питань (здобуття практичних навиків).

Для усунення таких недоліків автори розробили класичну систему, що дозволяє отримувати знання самостійно користувачами, використовуючи мережу Internet, базу даних, що зберігає на сервері навчальний контент. Така схема отримала назву інформаційна-дистанційно-тренажерна система (ІДТС) (рис. 11).

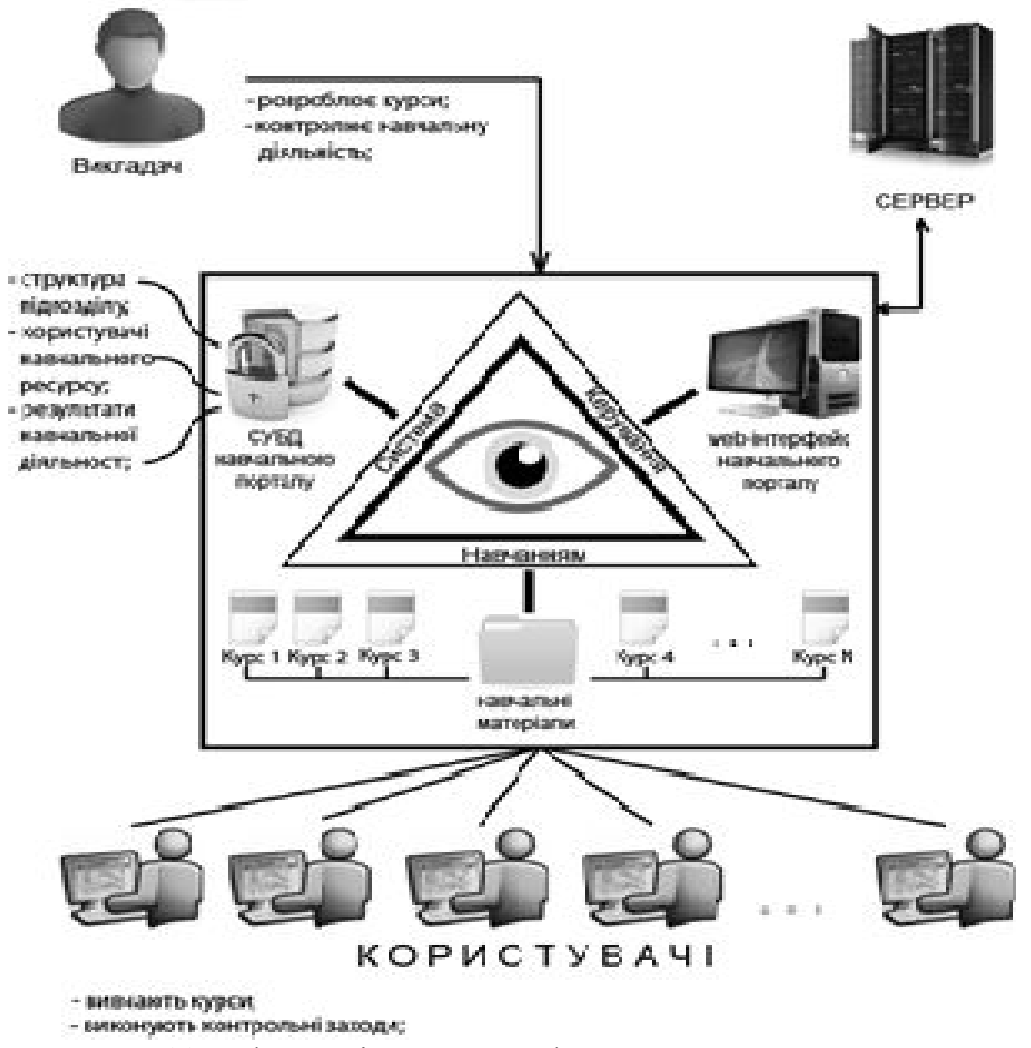

Рис. 11. Інформаційно-дистанційно-тренажерна система 
У більшості випадків навчальний контент таких систем - це набір навчальних матеріалів розроблюваних засобами Microsoft Office у текстовому або презентаційному вигляді та набір контрольних тестів, питань для перевірки вивченого матеріалу. 3 метою заохочення та мотивації засвоєння навчального контенту автори ввели кросворди, філворди та інші матеріали, що знімають загальні напруження, в той же час, спонукають до подальшого вивчення, викликаючи інтерес.

Основою ІДТС $є$ розроблені відеофільми та відеоролики на основі 3D моделювання, анімації дії вузлів ОВТ, боєприпасів тощо.

Iз викладеного вище випливає нагальна необхідність мотиваційних зусиль щодо підготовки фахівців з бажання прискорити процес навчання, удосконалити набуті навики, довести виконання операцій до автоматизму. Меню навчального контенту представлено на рис. 12.

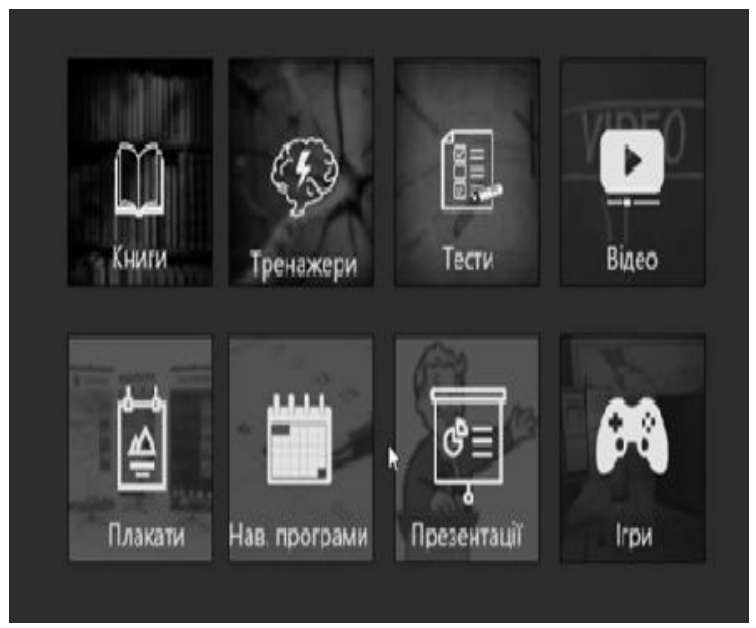

Рис. 12. Меню навчальної контенти

Порівнювальна характеристика рівня знань в залежності від тривалості застосування 3D моделювання на заняттях представлена на рис. 13.

3 рисунку видно, що для застосування 3Dмоделей на планових заняттях оптимальним часом $€$ 30-60 хвилин і $15-45$ хвилин на самостійній підготовці. Подальше зниження рівня засвоєння на планових заняттях і самостійній підготовці пояснюється стомленістю студентів за причини отримання великого обсягу інформації.

Отже, основним завданням ІДТС $є$ подальше

\section{Лimepamypa}

1. Дерев'янчук А.Й., Чопа Д.А., Дегтярьов В.В., Семенов Ф.Д. Кейс - метод як форма інтерактивного навчання 3 військово - технічних дисциплін при підготовці фахівців ракетних військ і артилерії. Сучасні інформаційні технології в сфері безпеки та оборони. НУОУ. 2019. №1(34). 2. Дерев'янчук А.Й., Чопа Д.А. Дегтярьов В.В. Інформаційні технології як технічна основа розвитку сучасних методів викладання військово-технічних дисциплін. Сучасні інформаційні технології в сфері безпеки та оборони. НУОУ. 2019. наповнення платформи новими матеріалами як власних розробок, так і інших ВВНЗ.

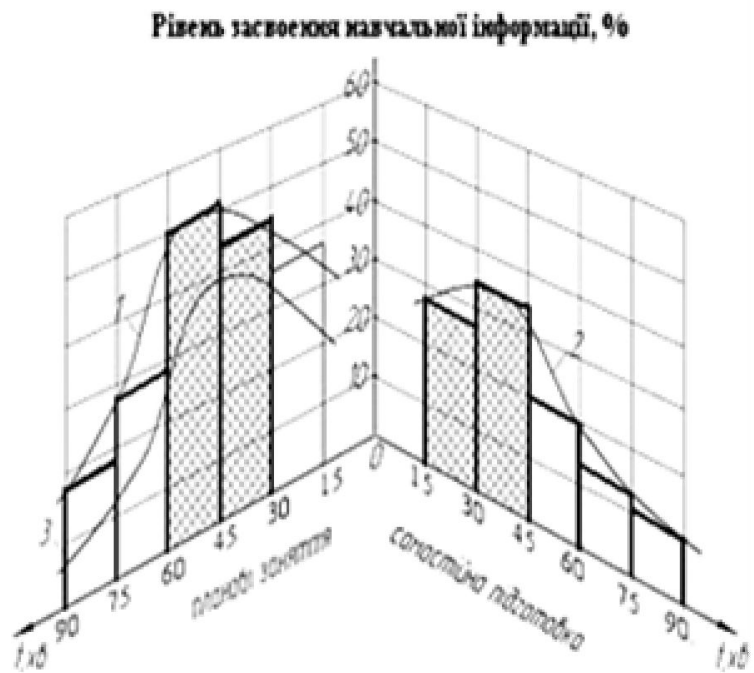

Рис. 13. Порівняльна характеристика рівня знань залежно від тривалості застосування 3D моделювання

На рис. 13 криві 1,2 відображають результати навчального процесу із використанням 3D моделювання на планових заняттях і самостійній підготовці відповідно, крива 3 - при відсутності у самостійній підготовці застосування 3D моделювання.

\section{Висновки і перспективи подальших досліджень}

Таким чином, у статті завершено розгляд основних інноваційних напрямів застосування інформаційних технологій у викладенні ВТД. Результати досліджень дозволяють зробити висновок щодо доцільності створення комплексу новітніх методик. Впровадження інформаційних технологій як технічної основи подальшого розвитку сучасних методів викладання військовотехнічних дисциплін дозволяє значно підвищити не тільки теоретичні знання, а й практичні навички.

Подальші дослідження вбачаємо у розширенні і наповненні вказаних методик сучасним контентом та їх удосконаленням, в розробленні тренажерів віртуальної реальності.

\section{ОСНОВНЫЕ ІННОВАЦИОННЫЕ НАПРАВЛЕНИЯ ПРИМЕНЕНИЯ СОВРЕМЕННЫХ ИНФОРМАЦИОННЫХ ТЕХНОЛОГИЙ В ПОДГОТОВКЕ ВОЕННЫХ СПЕЦИАЛИСТОВ}


Дмитрий Анатольевич Чопа (кандидат технических наук, с.н.с.) ${ }^{1}$

Анатолий Йосипович Деревьянчук (кандидат технических наук, профессор) ${ }^{2}$ Наталья Николаевна Козырь ${ }^{3}$

${ }^{1}$ Национальный университет обороны Украины имени Ивана Черняховского, Киев, Украина ${ }^{2}$ Сумськой государственный университет, Суммы, Украина

${ }^{3}$ Научно-исследовательский центр Ракетных войск и артиллерии, Суммы, Украина

Применение Вооруженных Сил Украины в современных условиях обусловливает новые требования к организации обучения и подготовки военных специалистов. Существует настоятельная необходимость в разработке новых технологий обучения, повышении уровня усвоения учебного материала и совершенствовании способов контроля его усвоения. Поэтому в статье на основе опьта кафедры военной подготовки Сумского государственного университета приводятся основнье инновачионные направления применения информационных технологий в подготовке военных специалистов (на примере специиалистов РВ и A). В частности, эта статья посвящена созданию мультимедийных виртуальных тренажеров (симуляторов), моделированию учебных игр, разработке системы автоматизированной оценки знаний и созданию информационно-дистанционно-тренажерньй системы обучения. Авторы статьи продолжают делиться собственным опытом кониепции применения современных методов преподавания военно-технических дисциплин с иелью дальнейшего их обсуждения, развития и внедрения в образовательный проиесс ВВУЗ.

Ключевые слова информационные технологии, мультимедийные виртуальные тренажеры (симуляторы) обучающие игры; системь автоматизированной оценки знаний; информационнодистаниионно-тренажерный система обучения.

\title{
GENERAL INNOVATIVE DIRECTIONS OF THE USE OF MODERN INFORMATION TECHNOLOGIES IN THE TRAINING OF MILITARY SPECIALISTS
}

\author{
Dmitro Chopa (Candidate of technical sciences, Senior Research Fellow) ${ }^{I}$ \\ Anatolii Derevianchuk (Candidate of technical sciences, professor) ${ }^{2}$ \\ Natalya Kozyr ${ }^{3}$ \\ ${ }^{1}$ National Defence University of Ukraine named after Ivan Cherniakhovsky, Kyiv, Ukraine \\ ${ }^{2}$ Sumy State University, Sumy, Ukraine \\ ${ }^{3}$ Artillery Research Center, Sumy, Ukraine
}

The use of the Armed Forces of Ukraine in modern conditions stipulates new requirements for the organization of education and training of military specialists. There is an urgent need to develop new learning technologies, increase the level of learning material and improve ways to control its learning. Therefore, in the article, based on the experience of the department of military training of Sumy State University, the main innovative directions of the use of information technologies in the training of military specialists are given (for example, artillery specialists). In particular, this article is devoted to the creation of multimedia virtual simulators (simulators), the simulation of educational games, the development of an automated knowledge assessment system and the creation of information and distance learning equipment. The authors of the article continue to share their own experience of the concept of applying modern methods of teaching military-technical disciplines for the purpose of further discussing them, developing and introducing them into the educational process of the higher military educational establishment.

Keywords: information technology, multimedia virtual simulators (simulators) educational games; automated knowledge assessment systems; information and distance learning system of training.

\section{References}

1. Derevyanchuk A., Chopa D., Dehtiarov V., Semenov F. (2019). Keis - metod yak forma interaktyvnoho navchannia $\mathrm{z}$ viiskovo - tekhnichnykh dystsyplin pry pidhotovtsi fakhivtsiv raketnykh viisk i artylerii [Casemethod as a form of interactive training on militarytechnical disciplines in preparation of artilery specialists]. Suchasni informatsiini tekhnolohii $\mathrm{u}$ sferi bezpeky ta oborony. NUOU. №1(34). 2. Derevyanchuk A., Chopa D., Dehtiarov V. (2019). Informatsiyni tehnologiyi yak tehnichna osnova rozvitku suchasnih metodiv vikladannya viysbkovo-tehnichnih distsiplin [Information technologies as a technical basis for the development of modern methods of teaching military-technical subjects]. Suchasni informatsiini tekhnolohii u sferi bezpeky ta oborony. NUOU. №2(35).
3. Obraztsov I., Belov V. Virtualnyie trenazheryi v praktike tehnicheskogo obrazovaniya [Virtual simulators in the practice of technical education] URL:http://cdokp.tstu.tver.ru/site.services/ download.aspx? act $=1 \&$ did $=89791 \&$ dbid=marcmain. $\quad$ 4. The first international scientific-practical conference (2018). Problemi vprovadzhennya distantsIynogo navchannya $\mathrm{v}$ osvItnomu protsesI vischih vlyskovih navchalnih zakladIv ta mozhlivI shlyahi Yih virIshennya. [Problems of introduction of distance learning in the educational process of higher military educational establishments and possible ways of solving them]. Collection of materials of the $1 \mathrm{st}$ international scientific-practical conference. Kyiv. 